\title{
COMPARISON OF NEUTRON MOISTURE GAUGES WITH NONNUCLEAR METHODS TO MEASURE FIELD SOIL WATER STATUS
}

\author{
C. KIRDA ${ }^{1}$ \& K. REICHARDT ${ }^{2}$
}

SUMMARY: The neutron moisture gauge is compared with the gravimetric-core soil sampling technique, tensiometers and resistance blocks in relation to stability, field variability, spatial dependence and number of samples needed at a given level of significance. The variance of field water content measurements with neutron moisture gauges is lower than that of the gravimetric sampling, which therefore requires 2 to 6 times as many samples as the number of measuring sites of the gauges to attain the same level of significance. The space dependence of the measurements made with the subsurface gauge varied depending on the average field soil water content. No space dependence was evident when the water content was lower than $0.2 \mathrm{~cm}^{3} . \mathrm{cm}^{-3}$ ( $50 \%$ saturation). Measurements with the tensiometers and resistance blocks manifested no spatial dependence and therefore randomly selected measuring sites can be adapted to field research work where these methods are to be utilized. Soil water content measurements estimated with neutron moisture gauges showed well defined temporal stability (i.e., the lowest, average and the highest soil water content measurements occur at the same field site) which implies that soil water status of an entire field can be assessed with measurements limited to few locations. Measurements with both tensiometers and the resistance blocks are time variant (i.e., the site giving field average water content changes spatially in time) owing to their relatively smaller measuring domains (i.e., scale of the area which can be represented by a single measurement) as compared to neutron gauges. Therefore it is not possible to define the measuring sites of the tensiometers and resistance blocks as to assess soil water status of the entire field, as it could be done with the neutron gauge.

Key Words: neutron gauges, tensiometers, resistance blocks, spatial variability, soil water.

\section{COMPARAÇ̃̃o de SONDAS DE NEUTRONS COM MÉTODOS NÃo NUCLEARES NA ESTIMATIVA dA ÁGJA No SOLO DM CONDÇÖES de CAMPO}

RESUMO: A sonda de neutrons é comparada com a amostragem gravimétrica, com a tensiometria e com o uso de blocos de resistência, em relação à estabilidade, variabilidade do campo, dependência espacial e múmero de amostras necessárias levando em conta determinado nível de significância. A variância das medidas de umidade do solo obtidas por sonda de neutrons é menor do que para a amostragem gravimétrica, que requer um número de amostras 2 a 6 vezes maior em relação à sonda de neutrons dentro de um mesmo nível de significância. A dependência espacial das medidas feitas com sondas de profundidade variou de acordo com os niveis de umidade do solo. Nenhuma dependência espacial ficou evidente para umidades menores que $0,2 \mathrm{~cm}^{3} . \mathrm{cm}^{3}(50 \% \mathrm{da}$ saturação). Medidas com tensiômetros e blocos de resistência não manifestaram dependência espacial e, por isso, a escolha das parcelas para medida facilmente se adaptam a esquemas experimentais nos quais estes métodos podem ser utilizados. Medidas de umidade de solo obtidas por sondas de neutrons mostraram uma estabilidade temporal bem definida (isto é, os valores menor, médio e mais alto de umidade do solo ocorrem na mesma posição no campo experimental) o que significa que o estado da umidade do solo de um campo relativamente grande pode ser determinado através de um número límitado de medidas. Medidas com tensiômetros e blocos de resistência são variáveis no tempo (isto $\mathrm{e}$, a parcela que indica a umidade média do campo varia espacialmente no tempo) devido a seus domínios de medida relativamente menores (isto $e$, tamanho da área que pode ser representada por uma única medida) em comparação com sondas de neutrons. Por isso não é possível definir

\footnotetext{
1 Joint FAO/LAEA Division, P.O.Box 100. A-1400 Vienna, Austria.

${ }^{2}$ Professor Titular do Departamento de Física e Meteorologia, ESALQ/USP. 13418-900 - Piracicaba,SP.
} 
posiçóes de medidas para tensiômetros e blocos de resistencia para caracterização da umidade do solo do campo todo, da forma como foi possivel para sondas de neutrons.

Descritores: sonda de neutrons, tensiometros, blocos de resistencia, variabilidade espacial, umidade do solo.

\section{INTRODUCTION}

The neutron scattering method has received world-wide popularity in soil water studies because it can provide very quick and non-destructive measurement of field soil water contents. However, traditional non-nuclear methods such as gravimetric sampling, tensiometers and resistance blocks are still being used, for the same purpose, in field research work. Since the pioneering works of GARDNER and KIRKHAM (1952) and VAN BAVEL $(1958,1963)$, a wide range of research has been carried out for the evaluation and improvement of the neutron scattering method (see for example IAEA, 1967; 1974; 1983; VACHAUD et al., 1977; GREACEN and HIGNETT, 1979; SINCLAIR and WILLIAMS, 1979; KASI, 1982; NAKAYAMA and REGINATO, 1982; HODGSON and CHAN, 1987; AMOOZEGAR et al., 1989). Similar attention has been given to the development of tensiometers (e.g., MILLER, 1951; MARSHALL, 1959; RICHARDS, 1960; KLUTE and GARDNER, 1962; VILLA NOVA et al, 1989) and of resistance blocks (e.g., BOUYOUCOS and MICK, 1940; BOUYOUCOS, 1949; TANNER et al., 1949; KIRKHAN and TAYLOR, 1950; PERRIER and MARSH, 1958). Tensiometers work only in the wet range of soil water content, up to soil water matrix pressures of about - $80 \mathrm{kPa}$ (MARSHALL, 1959). The resistance blocks complement the tensiometers and have good performance in the dry range. Gravimetric sampling is the oldest traditional method used to measure soil water content. It is the standard method against which all the other methods are to be calibrated. However, it is very laborious and the results can only be available after a minimum of one day. Different merits of the methods mentioned above vary depending on specific objectives of the research scientists who use them.

This work compares neutron moisture gauges with tensiometers, resistance blocks and with gravimetric sampling in the estimation of field-mean soil water content in regard to temporal stability, field variability, spatial dependence and number of sampling or measuring sites for a given level of significance.

\section{MATERIAL AND METHODS}

Data, subject to discussion here, were compiled along field transects so that geostatistical methods could be used in the comparison of the different methods. The space intervals of measurements (i.e., lag distances) in the field transects were 1.5 and $3 \mathrm{~m}$. Each year, the field transects were laid down in different sites within a 5 hectare research field.

Measurements made for comparison purposes were independent of the measurements for calibration. The soil used is classified as Typic Eutocrepts with coarse clay loam texture. It is an alluvial soil with compacted gravelly clay zone at about $0.5 \mathrm{~m}$ depth. The surface layer of 0.4 to $0.5 \mathrm{~m}$ appears rather stony with gravel content of about $30 \%$.

Two types of neutron moisture gauges, surface and subsurface types were used in field tests: Troxler 3411 series (combined water and density gauge) and CPN 503 DR.

Measurements made with neutron subsurface gauge were compared with those made with tensiometers and resistance blocks. The experimental plots of $3 \times 3 \mathrm{~m}$ where the different methods were compared, were planted alternated to maize, and the remaining plots were left bare.

Neutron access tubes were installed in the center of the plots. Tensiometers and resistance blocks were installed at $30 \mathrm{~cm}$ depth, $50 \mathrm{~cm}$ from the access tubes in order to avoid interference with neutron thermalization. Calibration of the neutron gauge was done at the end of growing season. The calibration was completed in two stages: (1) when soil water content was relatively dry $\left(0.12\right.$ to $\left.0.20 \mathrm{~cm}^{3} \cdot \mathrm{cm}^{-3}\right)$, and (2) when it was relatively wet $\left(0.25\right.$ to $\left.0.30 \mathrm{~cm}^{3} \cdot \mathrm{cm}^{-3}\right)$.

After neutron gauge measurements were made, in each case the measuring sites were excavated to collect gravimetric samples. A second set of measurements was obtained following irrigation to increase soil water content to the wet range (over 0.30 $\mathrm{cm}^{3} . \mathrm{cm}^{-3}$ ). At each stage, 20 (equally divided in bare and maize planted plots) gravimetric core soil samples were collected, with concurrently made neutron count rate measurements, using both surface and subsurface neutron gauges. The lines with data points are the estimates with tensiometers and the resistance blocks.

Autocorrelation analysis described by DAVIS (1973) was used to determine if soil water content measurements made with the different methods are spatially correlated. Two methods were used for sample number determination. The first method is based on the 


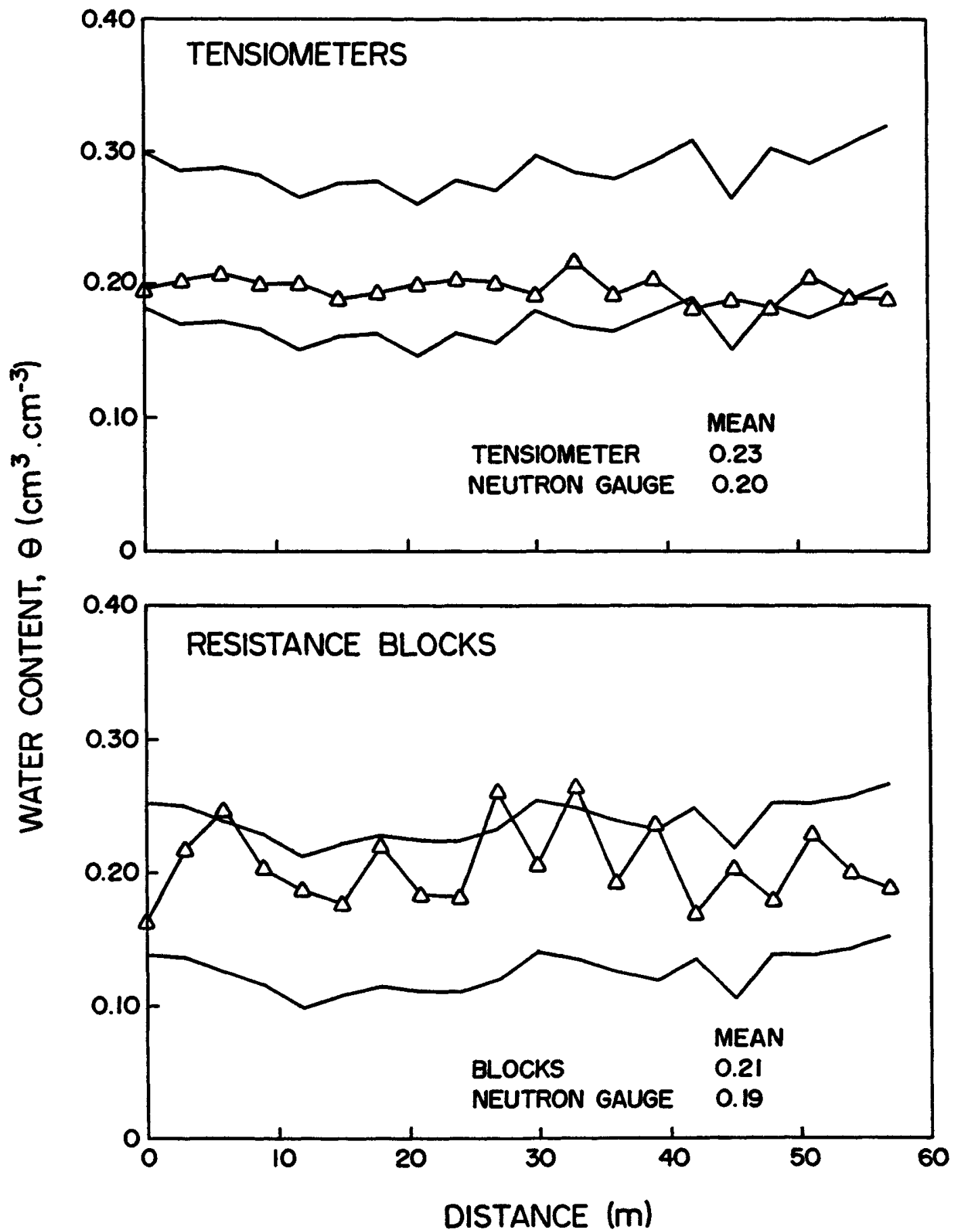

Figure 1. Spatial distribution of field soil water content measurements at $30 \mathrm{~cm}$ soil depth, measured with neutron moisture gauge and nonnuclear traditional methods, tensiometers and resistance blocks. The solid lines show $95 \%$ confidence interval of the estimates of soil water content measured with neutron gauges. 
assumption that the measurements are normally distributed, and that the accurate estimate of its variance is known. The number of samples $N$ necessary to be within the $\pm d$ units of the field mean with $(1$ $\alpha) \%$ confidence is (HAJRASULIHA et al, 1980; KIRDA 1980; HENDRICKS and WIERANGA, 1990):

$$
N=[Z \sigma / d]^{2}
$$

where $\mathrm{Z}$ is $(\mathrm{X}-\mu) / \sigma, \sigma^{2}$ the population variance, $\mu$ the population mean and $d$ is half width of the confidence interval. For values of $\alpha=0.1, Z$ is 1.64 .

The second method (HENDRICKS and WIERANGA 1990) is recommended for situations where there is no accurate estimate of variance. This method yields a conservatively high sample number, however, it gives a higher assurance that the true mean will indeed fall within $\pm d$ units of the estimated mean. The sample number $\mathbf{N}$ is given as

$$
N=\frac{t \alpha^{2}, n-1 . F \alpha, n-1, n-1 . s^{2}}{d^{2}}
$$

where $t$ is Student's $t$ with ( $n-1)$ degrees of freedom, $\alpha$ the assumed probability that half width of the confidence interval will not be exceeded; $F$ the tabulated variance ratio with identical degrees of freedom (n-1) for both the numerator and denominator of the $F$ distribution function, and $s^{2}$ the sample variance.

\section{RESULTS AND DISCUSSION}

Field soil water content measurements, estimated with tensiometers and resistance blocks were mostly confined within the limits of $95 \%$ confidence interval $\left( \pm 0.06 \mathrm{~cm}^{3} . \mathrm{cm}^{-3}\right)$ of the neutron moisture gauge estimates (Fig. 1). The field mean values of water contents measured with tensiometers and resistance blocks deviated slightly from those estimated with neutron moisture gauge (Fig. 1). The deviation can further be reduced if one can invest the same effort in their calibration as spent in the calibration of the neutron moisture gauges.

Figure 2 compares autocorrelograms of soil water content measurements, made with subsurface neutron gauge and tensiometers. Neither soil matrix pressure nor soil water content, which are respectively measured directly and indirectly with the tensiometers, show spatial dependence. On the other hand, neutron

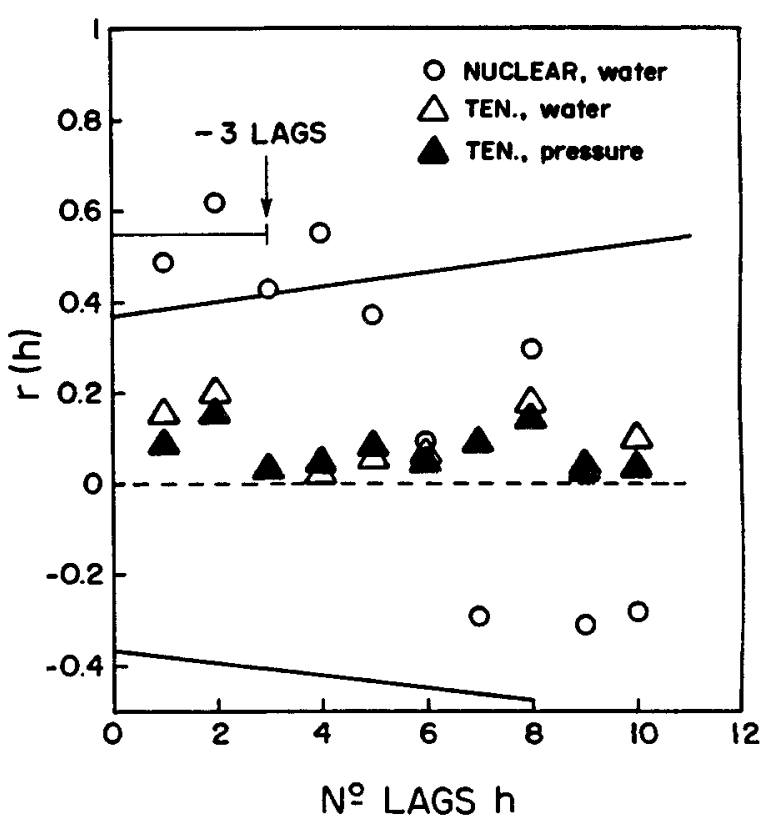

Figure 2. Autocorrelograms of the neutron gauge and the tensiometer measurements. Solid lines show $95 \%$ confidence interval of random variabitily.

gauge measurements manifest a distinct spatial dependence over a distance of 3 lags $(9 \mathrm{~m})$. This implies that the measurement domains of the two methods, tensiometers and the neutron gauges, are not the same. While the measurements with the neutron gauge are spatially correlated within a distance of $9 \mathrm{~m}$, the tensiometer measurements show a random distribution. The spatial dependence, manifested in neutron gauge measurements, has both advantages, and conversely, some consequences which must be considered in agricultural research: (1) a single measurement made with a neutron gauge represents relatively larger area in the field (which in our case can be seen as a circular area with a radius of $9 \mathrm{~m}$ ) than that of tensiometers; (2) soil water characteristic curves can be determined with concurrent use of tensiometers and the neutron gauge in field experiments. In this case, tensiometers can be installed at any convenient distance from the neutron access tubes, up to $9 \mathrm{~m}$ for this field; (3) field experiment designs must consider the spatial dependence of water content measurements, and a 


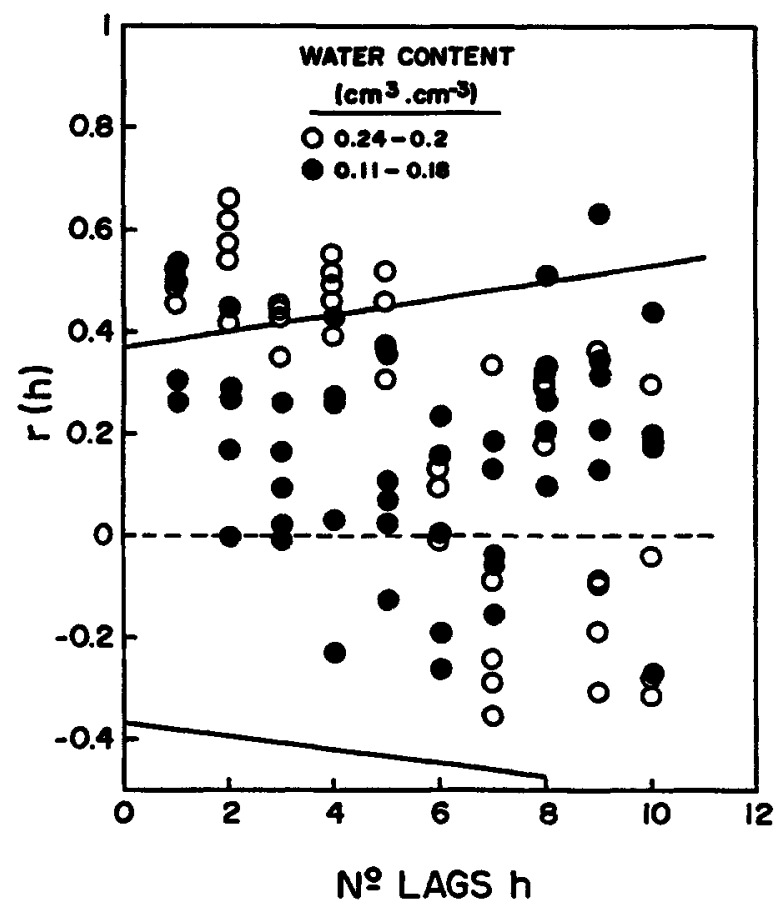

Figura 3 - Influence of soil water status, high and low water contents, on spatial dependence of the water content measurement. Solid lines show $95 \%$ confidence interval of random variability.

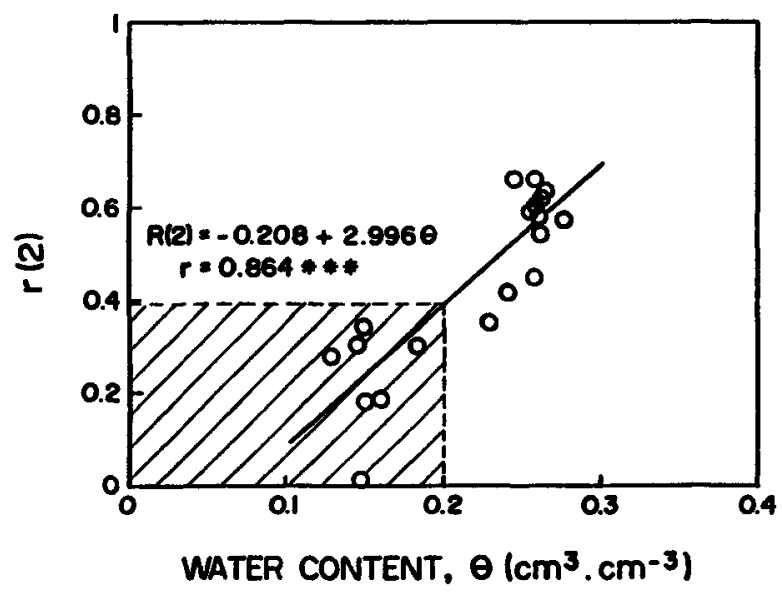

Figure 4 - Dependence of aucorrelation coefficient at lag $=2, r(2)$, on field soil water status. The shaded area shows $95 \%$ confidence range of random variability of field water content measurements. distance of more than $9 \mathrm{~m}$, in the experimental soil used in this study, must be allowed between the centroids of the experimental plots, where water content measurements are made with neutron moisture gauges. Spatial dependence of the neutron gauge measurements was more evident at high field soil water contents ( $>$ $\left.0,20 \mathrm{~cm}^{3} . \mathrm{cm}^{-3}\right)$, and it decreased as the water content decreased (Fig. 3). Autoccorrelation coefficients for lag $=2$, shown in Figure 4, manifested a strong association with water content measurements. The results therefore suggest that highly heterogeneous nature of the physical soil properties, influencing water storage capacity of the experimental soil, become more apparent at high water contents, from 0.24 to 0.27 $\mathrm{cm}^{3} \cdot \mathrm{cm}^{-3}$ (over $75 \%$ saturation), than lower water contents, from 0.11 to $0.18 \mathrm{~cm}^{3} . \mathrm{cm}^{-3}$ (below $50 \%$ saturation).

Both surface an subsurface neutron gauge measurements were compared with the destructive, gravimetric core-sampling method, in a separate site of the field, other than the one where the neutron gauges were calibrated. The site was bare soil. Measurements were made at $1.5 \mathrm{~m}$ equally spaced measuring sites, along the field transects. For surface and subsurface neutron moisture gauges, 30 and 48 measuring sites were used, respectively. The depth of measurements for the subsurface gauge was $30 \mathrm{~cm}$. After neutron gauge measurements were completed, the sites were excavated to collect cylindrical core soil samples, with $10 \mathrm{~cm}$ height and $10 \mathrm{~cm}$ diameter. Spatial distribution of water contents, measured with neutron gauge and the gravimetric sampling are shown in Figure 5. Soil water content estimates made with neutron moisture gauges follow very closely the spatial distribution manifested with the gravimetric sampling. There was no statistically significant difference $(P<0.05)$ between the field mean estimates of water content with both, the neutron moisture gauges and the gravimetric sampling.

Autocorrelograms (Davis, 1973), not shown here, indicated that water content measurements with both gravimetric sampling and the neutron scattering method had spatial dependence with similar autocorrelation distance. To determine number of measuring sites or number of samples in different methods, for estimation of field mean water content to be $\pm 10 \%$ deviation of the true mean $(\mu)$ with $90 \%$ confidence, equations [1] and [2] were used. In cases where the data was space dependent, the sample mean and the variance were calculated using sub-sample sets within individual observations selected outside the autocorrelation distance. For example, comparing subsurface neutron moisture gauge with the gravimetric 


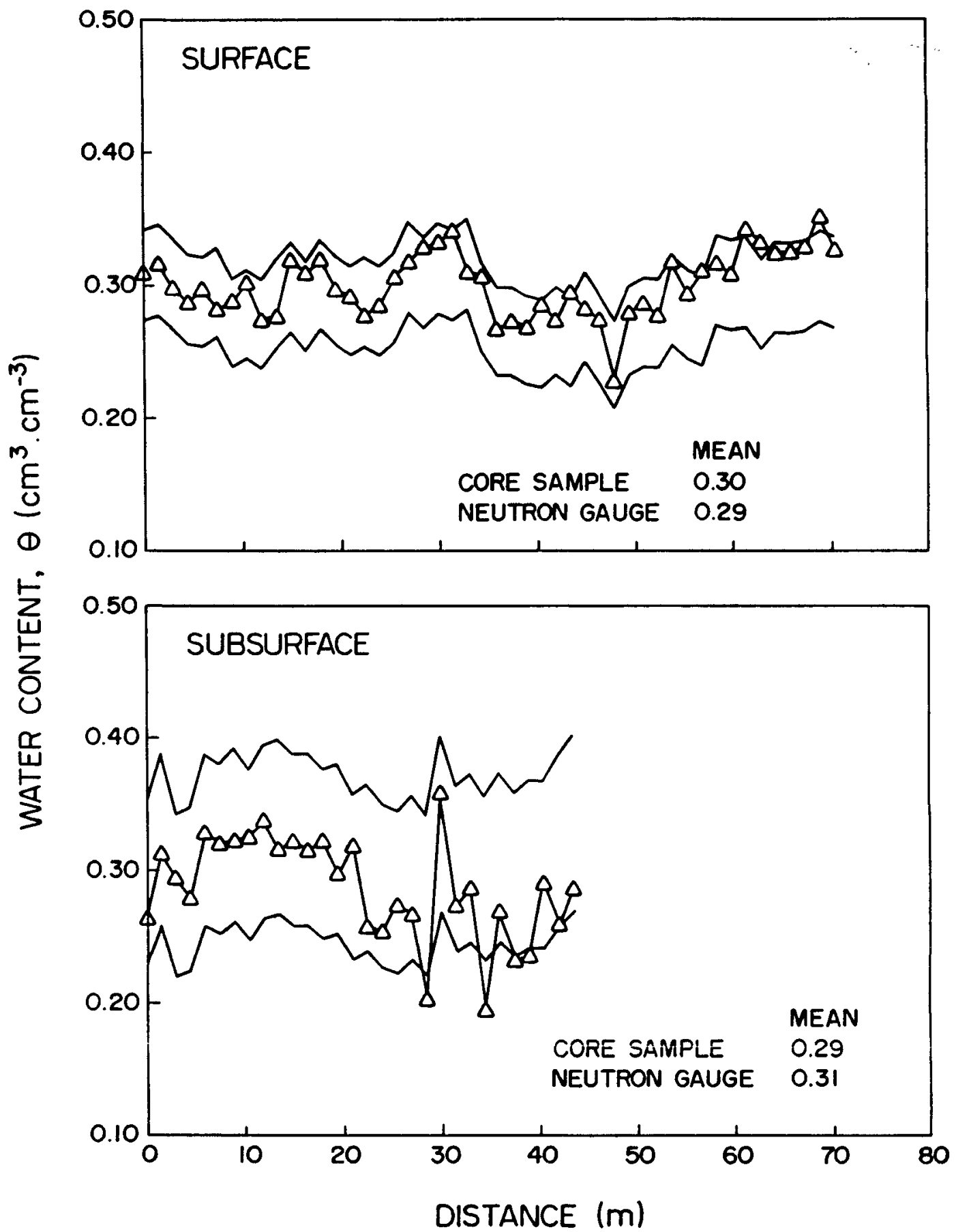

Figure 5. Spatial distribution of field water content measured with gravimetric core soil sampling and the neutron gauges. The solid lines show $95 \%$ confidence interval of the estimates of the soil water content, 


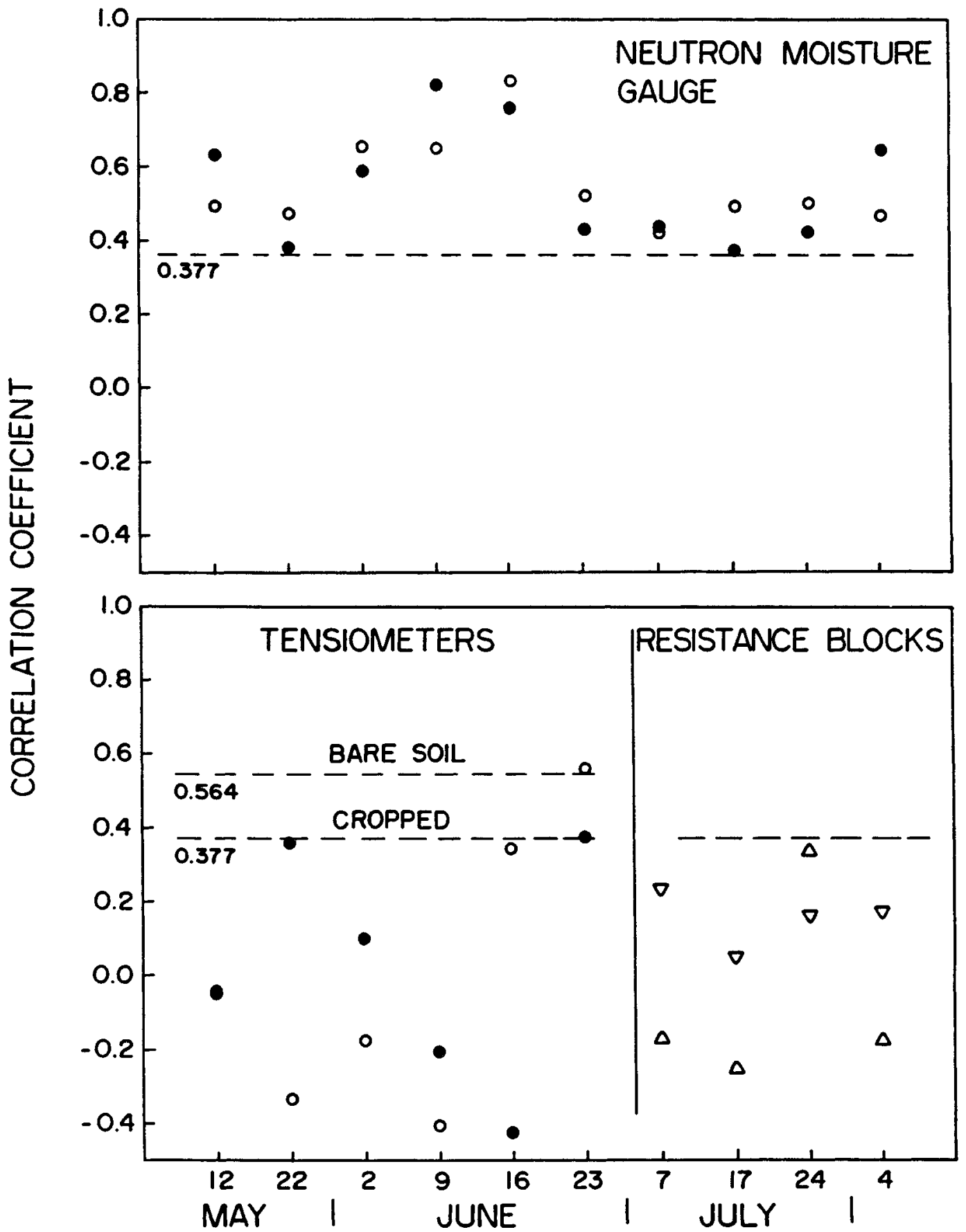

Figure 6. Spearman's rank correlation coefficients between the first day of water content measurements (28 April for the neutron gauge and the tensiometers, 26 June for the resistance blocks) and of other measurement days. The solid and the open points designate measurements in cropped and bare soil plots, respectively. The broken lines indicate minimum correlation coefficient at $5 \%$ significance (which was 0.377 for all measurements and for the tensiometers in bare soil where it was 0.564 ). 
sampling, only half of the total 30 measurements could be used to satisfy the prerequisite of the independent measurements to calculate the necessary statistics.

Variance of water content measurements with neutron moisture gauge are rather small and therefore the total number of measuring sites to allow the true mean to be within $\pm 10 \%$ deviation of the sample mean, with $90 \%$ confidence, vary within a very small range, from 1 to 4 , or from 2 to 9 , depending on whether equation [1] or [2] is used (Table 1). Variance of measurements with the gravimetric sampling, when compared with the neutron gauge measurements, is higher. Therefore, 2 to 6 times as many samples as the number of neutron gauge measuring sites are to attain the same level of accuracy (Table 1). Number of samples required for tensiometers and resistance block measurements varies depending on whether soil matrix pressure or soil water content is measured. Although variance of matrix pressure measurements is very high for tensiometers and resistance blocks, it is lower in units of water content when compared with neutron gauge measurements (Table 1). Therefore, in contrast to the gravimetric sampling, the number of tensiometers and of resistance blocks needed are 2 to 6 times less than the number of neutron gauge measuring sites to attain the same soil water content level of significance as the neutron gauge measurements. However having somewhat smaller number of measuring sites for the tensiometers or resistance blocks, the well established advantages of the neutron scattering method should not be outweighed. For example, with a single neutron access tube one can measure changes of soil water storage over the complete plant rooting depth, where as one would need several tensiometers and resistance blocks, depending on the rooting depth, installed at different depths.

It is also of interest to compare different methods as regards to temporal stability; i.e., if the lowest, average, and the highest soil water content measurements always occur at the same-site for a given method. VACHAUD et al. (1985) demonstrated the occurrence of such a feature for soil water content measurements, and explained the observed behavior with the deterministic relation existing between soil water content and soil texture, i.e., a field location with the highest clay content remains the wettest at all times. KIRDA and REICHARDT (1986) showed that temporal stability of water content measurements would not be perturbed even under different crops. The existence of temporal stability of water content measurements could allow the assessment of soil water status of an entire field with measurements made only at a few sites.
Temporal stability of soil water status as measured with different methods was compared using Spearman's rank correlation test (VACHAUD et al, 1985). The correlation coefficients between the ranks of the first day measurements (28 April for the neutron gauge and the tensiometers, 26 June for the resistance blocks) and the ranks of other 10 sets of data collected nearly at 2 week intervals over a 3 months period (May, June and July) were compared. The correlation coefficients of the neutron gauge measurements, both in cropped and in bare soil plots, were all significant ( $P$ $<0.05$ ), whereas the correlation coefficients of the tensiometers and the resistance blocks were not significant (Fig. 6). Our results therefore suggest that it is indeed possible to assess soil water status of an entire field with neutron gauge measurements limited only to a few sites. However, this is not possible with tensiometers and the resistance blocks which have to be installed in randomly selected measuring sites, and in considerably higher number than the neutron gauges. The reason why tensiometer and resistance block measurements could not manifest temporal stability lays in the extreme textural variability of the experimental site, which is essentially an alluvial deposition, mixture of sand and gravel, and compacted packs of clay. The neutron gauge measurements gave an average water content integrated over a relatively large 'sphere of influence' than tensiometers and resistance blocks and therefore, the influence of soil variability on the temporal stability was minimal.

\section{CONCLUSIONS}

1. Field soil water content measurements with both the gravimetric core-soil sampling and the neutron gauge have the same spatial variance structure, i.e., the measurements with both methods are either space dependent or randomly distributed. If they are space dependent, it is not critical to take the core soil samples very close to the neutron gauge access tubes, but the samples can be taken in any convenient distance within the limits of the autocerrelation length (i.e., the distance over which the measurements are correlated), during the calibration of the gauges, provided of course, spatial changes with respect to water content are not significant. If the measurements do not show any space dependence, the core samples during the calibration must be taken immediately adjacent to the access tubes.

2. Spatial dependence of the neutron gauge measurements varies depending on soil water content, and it is increased as field soil water content increases 
Table 1 - Comparison of the different methods for number of samples required to have estimated mean with \pm $10 \%$ deviation from true mean, with $90 \%$ confidence.

\begin{tabular}{|c|c|c|c|c|c|c|c|c|}
\hline \multirow[t]{2}{*}{ Date } & \multirow[t]{2}{*}{ Method } & \multirow[t]{2}{*}{ Unit } & \multirow{2}{*}{$\begin{array}{l}\text { Total } \mathrm{a}^{\circ} \\
\text { of Data }\end{array}$} & \multirow{2}{*}{$\begin{array}{l}N^{\bullet} \text { of Data } \\
\text { space inde- } \\
\text { pendent sub-set }\end{array}$} & \multirow[t]{2}{*}{ Mean } & \multirow{2}{*}{$\begin{array}{l}\text { STD. } \\
\text { DEV. }\end{array}$} & \multicolumn{2}{|c|}{$N^{\circ}$ OF SAMPLES } \\
\hline & & & & & & & Eq. (1) & Eq. (2) \\
\hline $23 / 06 / 76$ & Nuclear & $\mathrm{cm}^{3} \cdot \mathrm{cm}^{-3}$ & 20 & 10 & 0.242 & 0.035 & 2 & 5 \\
\hline $23 / 06 / 86$ & Tensiom. & $\mathbf{k P a}$ & 19 & - & -17.5 & 49.8 & 44 & 96 \\
\hline $23 / 06 / 86$ & Estimat.* & $\mathbf{k P a}$ & 20 & 10 & $-11,0$ & - & 1 & 2 \\
\hline $13 / 07 / 86$ & Nuclear & $\mathrm{cm}^{3} \cdot \mathrm{cm}^{-3}$ & 20 & - & 0.183 & 0.022 & 2 & 4 \\
\hline $13 / 07 / 86$ & Tensiom. & $\mathbf{k P a}$ & 18 & - & -70.8 & 241.9 & 13 & 30 \\
\hline $13 / 07 / 86$ & Estimat.* & $\mathbf{k P a}$ & 20 & - & -43.5 & - & 1 & 1 \\
\hline $24 / 07 / 86$ & Nuclear & $\mathrm{cm}^{3} \cdot \mathrm{cm}^{-3}$ & 20 & - & 0.146 & 0.034 & 4 & 9 \\
\hline $24 / 07 / 86$ & Block & $\mathbf{k P a}$ & 19 & - & -1022 & 13417 & 36 & 77 \\
\hline $24 / 07 / 86$ & Estimat.* & $\mathbf{k P a}$ & 20 & - & -650 & - & 1 & 2 \\
\hline $05 / 85$ & Nuclear & $\mathrm{cm}^{3} \cdot \mathrm{cm}^{-3}$ & 30 & 15 & 0.308 & 0.027 & 1 & 2 \\
\hline $05 / 85$ & Gravimet. & $\mathrm{cm}^{3} \cdot \mathrm{cm}^{-3}$ & 30 & 15 & 0.288 & 0.149 & 5 & 12 \\
\hline $06 / 85$ & Nuclear & $\mathrm{cm}^{3} \cdot \mathrm{cm}^{-3}$ & 48 & 16 & 0.287 & 0.032 & 1 & 3 \\
\hline $06 / 85$ & Gravimetr. & $\mathrm{cm}^{3} . \mathrm{cm}^{-3}$ & 48 & 16 & 0.302 & 0.059 & 2 & 4 \\
\hline
\end{tabular}

* Soil matrix pressure equivalent of $10 \%$ deviation of the mean field water content which was measured with the neutron gauge.

to values higher than $75 \%$ of soil saturation.

3. Field soil water content measurements estimated with neutron moisture gauges show temporal stability which persists irrespective of whether the measuring sites are planted or left fallow. This implies that it is possible to assess soil water status of an entire field with neutron moisture gauge measurements limited to only a few sites. However, this is not possible with tensiometers and the resistance blocks owing to their relatively smaller measuring domains as compared to the neutron moisture gauge.

4. Users need relatively more numbers of samples with the gravimetric sampling than the measuring sites of the neutron gauges to attain the same level of significance, i.e., to allow, for example, estimated field mean water content to be within $\pm 10 \%$ deviation of the true mean, at $90 \%$ confidence.

5. Variance of soil water content measurements, estimated indirectly with tensiometers and the resistance blocks, is lower than that of the neutron gauge measurements because the high variability observed in soil matrix pressure measurements can be eliminated in the estimation of water content, using soil water characteristic curves for the clay soils. Nevertheless, users would still need more units of tensiometers and resistance blocks than the number of the measuring sites of the neutron gauges to monitor changes of soil water over the entire plant rooting depth. One needs several units of tensiometers or resistance blocks to measure soil water content at different depths, whereas only one access tube would be adequate for the neutron moisture gauge.

\section{ACKNOWLEDGMENTS}

We thank Mr. N. Haselberger and O. Milosevic, IAEA staff and Mr. K.C. Eom and A.H. Al Asfar and Ms. R. Chinpituk and A. Florentino, IAEA fellows, at the IAEA Laboratories, for their assistance in the field work.

\section{BIBLIOGRAPHY}

AMOOZEGAR, A.; MARTIN, K.C.; HOOVER, M.T. Effect of access hole properties on soil water content determination by neutron thermalization. Journal of Soil Science Society of America. Madison. 53:330-5, 1989.

BOUYOUCOS, G.J. Nylon electrical resistance unit for continuous measurement of soil moisture in the field. Soil 
Science, Baltimore, 67:319-30, 1949.

BOUYOUCOS, G.T. \& MICK, A.H. An eleetrical resistance method for the continuous measurement of soil moisture under field conditions. East Lansing, Michigan Agricultural Experiment Station. 1940. (Technical Bulletin, 172).

DAVIS, J.C. Statistics and data analysis in geology. New York, John Wiley and Sons, 1973. 550p.

GARDNER, W. \& KIRHAM, D. Determination of soil moisture by neutron scattering. Soil Science, Baltimore, 73:791-401, 1952.

GREACEN, E.L. \& HIGNETT, C.T. Sources of bias in the field calibration of a neutron meter. Australian Journal of Soil Research. Melbourne, 17:405-15, 1979.

HAJRASULIHA, S.; BANIABBASE, N.; METTHEY, J.; NIELSEN, D.R. Spatial variability of soil sampling for salinity studies on Southwest Iran. Irrigation Science, New York, 1:197-208, 1980.

HENDRICKS, J.M.H. \& WIERANGA, P.J. Variability of soil water tension in a trickle irrigated chile pepper field. Irrigation Science. New York, 11: 23-30, 1990.

HODGSON, A.S. \& CHAN, K.Y. Field calibration of a neutron moisture meter in a cracking Grey Clay. Irrigation Science. New York, 8:233-40, 1987.

INTERNATIONAL SYMPOSIUM ON ISOTOPE AND RADIATION TECHNIQUES IN SOIL PHYSICS AND IRRIGATION STUDIES. Istanbul, 1967. Proceedings. Vienna, IAEA, 1967. 446p.

INTERNATIONAL SYMPOSIUM ON ISOTOPE AND RADIATION TECHNIQUES IN SOIL PHYSICS AND IRRIGATION STUDIES. Vienna, 1973. Vienna, IAEA, 1974. 517p.

INTERNATIONAL SYMPOSIUM ON ISOTOPE AND RADIATION TECHNIQUES IN SOIL PHYSICS AND IRRIGATION STUDIES. Aix-en-Provence, 1983. Procedings. Vienna, IAEA, 1983. 597p.

KASI, S.S.H. An attempt to calculate correctly the region of influence in gaugin moisture with neutrons. International Journal of Applied Radiation and Isotopes, New York, 33:667-71, 1982.

KIRDA, $C$. The confidence relations as affected by number of samples in various laboratory measurements of saline and sodium addected soils. Doga Bilim Dergisi, Ankara, 6(3):111-8, 1980.

KIRDA, C. \& REICHARDT, K. Measurement problems associated with soil water studies using nuclear techniques. In: WORKSHOP OF THE INTERNATIONAL LIVESTOCK CENTER FOR AFRICA, Adis Ababa, 1985. Potentials of forage legumes in farming systems of Sub-Saharan Africa; Proceedings, edited by I. Haque e outros. Adis Ababa, 1986. p.121-40.

KIRKHAM, D. \& TAYLOR, G.S. Some tests of fourelectrode probe for soil moisture measurement. Proceedings of Soil Science Society of America. Madison, 14: 42-6, 1950.

KLUTE, A. \& GARDNER, W.R. Tensiometer response time. Soil Science, Baltimore, 93: 204-7, 1962.

MARSHALL, T.J. Relation between water and soil. Farnham Royal, Commonwealth Agricultural Bureau, 1959. (Technical Communication, 50).

MILLER, R.D. A technique for measuring tensions in rapidly changing systems. Soil Science, Baltimore, 72: 291-301, 1951 .

NAKAYAMA, F.S. \& REGINATO, R.J. Simplifying neutron moisture calibration. Soil Science, Baltimore, 133: 48$52,1982$.

PERRIER, E.R. \& MARSH, A.W. Performance characteristic of various electrical resistance units and gypsum material. Soil Science, Baltimore, 86: 140-47, 1958.

RICHARD, L.A. Methods for measuring soil water tension. Soil Science, Baltimore, 68: 95-112, 1949.

RICHARDS, L.R. Advances in soil physics. In: INTERNATIONAL CONGRESS OF SOIL SCIENCE, 7., Madison, 1960. Transactions. Madison, 1960. v.1, p.67-79.

SINCLAIR, D.F. \& WILLIAMS, J. Components of variance involved in estimating soil water content and water change using a neutron moisture meter. Australian Journal of Soil Research, Melbourne, 17: 237-47, 1979.

TANNER, C.B.; ABRAMS, E.; ZUBRISKI, J.C. Gypsum moisture block calibration based on electrical conductivity in distilled water. Proceedings of Soil Science Society of America, Madison, 13:62-5, 1949.

VACHAUD, G.; PASSERAT DE SILANE, A.; BALABANIS, P.; VAUCLIN, M. Temporal stability measured soil water probability density function. Joumal of Soil Science Society of America, Madison, 49: 822$7,1985$. 
VACHAUD, G.; ROYER, J.M.; COOPER, J.D. Comparison of methods of calibration of a neutron probe by gravimetry of neutron-capture model. Journal of Hidrology, Amsterdam, 34: 343-56, 1977.

VAN BADEL, C.H.M. Measurement of soil moisture content by the neutron method. Washington, USDA/Agricultural Research Service, 1958. p.41-74.

VAN BADEL, C.H.M. Neutron scattering measurement of soil moisture: development and current status. In: INTERNATIONAL SYMPOSIUM ON HUMIDITY AND MOISTURE, Washington, 1963. Proceedings. Washington, 1963. p.171-84.

VILLA-NOVA, N.A.; REICHARDT, K.; LIBARDI, P.L.; MORAES, S.O. Direct reading "air-pocket" tensiometer. Soil Technology, Cremlingen-Destedt, 2: 403-7, 1989. 